Article

\title{
Polish Nationwide Catholic Opinion-Forming Weeklies on Social Media-From Theoretical Introduction to Empirical Approach
}

\author{
Andrzej Adamski ${ }^{1, *(\mathbb{D}}$, Anna Jupowicz-Ginalska ${ }^{2}\left[\right.$ and Iwona Leonowicz-Bukała ${ }^{1} \mathbb{C}$ \\ 1 College of Media and Social Communication, University of Information Technology and Management in \\ Rzeszow, ul. Sucharskiego 2, 35-225 Rzeszow, Poland; ileonowicz@wsiz.rzeszow.pl \\ 2 The Faculty of Journalism, Information and Book Studies, University of Warsaw, ul. Bednarska 2/4, \\ 00-310 Warsaw, Poland; a.ginalska@uw.edu.pl \\ * Correspondence: aadamski@wsiz.rzeszow.pl
}

Received: 9 March 2020; Accepted: 11 April 2020; Published: 16 April 2020

\begin{abstract}
This paper is the first part of a cycle comprising five texts on the marketing use of social media by nationwide opinion-forming Catholic weeklies in Poland. Considering the state of the research so far, it is not completely clear how to classify Catholic media profiles on social networking sites. On the one hand, the media activity of the Church is typically evangelistic in nature, but on the other hand it takes place in typically secular conditions. The evangelising role of the Catholic media cannot be separated from the opinion-forming function. The main objective of the project is, firstly, to assess the marketing potential of social media used by the aforementioned weeklies and secondly, to complement the previously described online presence of religious entities in the context of the mediatization of religions. This paper-as the theoretical background of the research-presents the detailed interdisciplinary literature review on the issues crucial for the project, as well as the methodological introduction to our study.
\end{abstract}

Keywords: social media; catholic media; Polish media; mediatization; evangelisation; media marketing

\section{Introduction}

This paper is the first part of a cycle comprising five texts on the marketing use of social media by nationwide opinion-forming Catholic weeklies. It is of an interdisciplinary nature. It should be attributed to the studies on social communication and media, but it also contains references to marketing, culture studies, religion, theology and canon law. As a theoretical basis, it is necessary to refer to American functionalism in the view of Robert Merton (2002), who provided an approach and a conceptual apparatus used later in the analysis (based on the messages published by the broadcasters rather than on an audience survey).

The main objective of the research project is, firstly, to assess the marketing potential of social media used by Polish Catholic opinion-forming weeklies (in a longer perspective: all Catholic and religious media in Poland), secondly, to complement the previously described online presence of religious entities in the context of the mediatization of religions and religious institutions and thirdly, to enrich Polish studies on these issues with a new marketing perspective.

The individual papers refer to:

- The theoretical introduction (this one)-a foundation for;

- The analysis of the marketing aspect of using Facebook (FB) by the selected weeklies (text 2, empirical);

- The analysis of the marketing aspect of using Twitter (TT) by the selected weeklies (text 3, empirical); 
- The analysis of the marketing aspect of using Instagram (IG) and YouTube (YT) by the selected weeklies (text 4, empirical);

- The summary of the research in the form of a comparative analysis, estimating the scale of the social media use by Catholic weeklies and developing recommendations for professionalising the activities undertaken (text 5, empirical).

It should be noted that the following stages of the project are: (1) an analysis of the social media marketing activity of Catholic radio stations, TV channels and Internet websites, and (2) a similar study of media dedicated to other religions (the Orthodox Church, Protestant churches, Islam and Judaism).

As indicated, this text initiates the entire cycle: therefore, it fulfils two overarching research goals. Firstly, it sets the theoretical foundation for further research on the marketing use of social media by Polish Catholic weeklies. Secondly, it presents the idea of the entire research project, along with its detailed research questions and methodological approach.

Taking the first aspect into consideration, this article carries out a literature review regarding the close relations between religion, Catholic media and social media. The authors undertook an analysis of the subsequent thematic topics, ranging from general issues (such as the mediatization of religion and also religious marketing), to more specific (the concept and definition of Catholic media in Poland, the description of the Polish Catholic weeklies including their online incarnations), to the analysis of the theoretical approach to the use of social media by the traditional media (conducted from a marketing perspective).

Taking the second aspect into consideration, this article also indicates the research framework for the entire project, presenting its objectives, questions and research methods. The authors decided that a detailed description of the project was necessary because it would facilitate further work on the articles 2, 3, 4 (that is, in their methodological parts the authors focused only on issues related to a given research thread, not the entire project). It should be emphasized that the authors of this paper did not aim to present the results of the empirical research carried out for the project here, because these-due to the large number and richness of the threads-will be discussed in the separate papers, devoted to each analysed social media platform.

It is also worth mentioning that the literature review was a research method implemented for this article, as its main research thesis was that in the field of literature on the subject (i.e., regarding the marketing use of social media by the Catholic media) there are significant academic gaps that need to be closed. The latter approach is close to the one of Günther and Domahidi (2017, p. 3051) who analysed a "metaknowledge" phenomenon (based on Evans \& Foster approach from 2011) as gaining "knowledge about knowledge to be able to identify the process of scientific production and to define academic gaps as well as future directions for research".

\section{State of the Art. Media and Religion: Interdisciplinary Research Perspectives}

According to Hoover (2011, p. 613), “[ ... ]media and religion are no longer separate 'spheres'; rather that they are evolving in a kind of dialectic relationship, and that it is not possible to understand either fully without reference to the other". Religion and media are converging and also academic research over media and religion are converging (Hoover 1997, 2002, p. 28). The academic study of the relationship between religion and the media is multi-faceted and multidisciplinary, due to the complexity of both phenomena. Religion and religious institutions may be of interest to sociology, political studies, management studies, culture studies, legal studies, etc. Each of these academic fields of study captures the reality of religion in its own way. The same is true of the media, which can be of interest to e.g., sociologists, educators, linguists, philosophers or theologians (not only media scientists).

The research topic undertaken here is of an innovative nature, as it focuses on the marketing context rather than on the historical, opinion-forming and evangelising aspect. Nevertheless, the analysis of the results of the research conducted for the purposes of this cycle would be impossible without the media being viewed from a Catholic theological perspective. As part of the research project, the profiles of the Catholic media were analysed: therefore, the authors wished to verify whether 
particular editorial boards take the theological perspective into account there, or whether they focus mainly on the marketing aspect.

The analysis of the state of scientific research revealed a huge number of scientific studies devoted to the relationship between the Church and the media, yet with a great prevalence of a theological perspective and written from a pastoral point of view. There should be no surprise in this regard, as the Catholic Church gives priority to theological thought, concerning the sources and foundations of its identity, but also due to the specificity of its sources and scientific and conceptual apparatus, going beyond the paradigm of other fields of science (Adamski 2013, p. 45). Theology deals with God and/or other matters in their relationship to God, hence it may consider various issues, but always sub ratione Dei (Seweryniak 2010, p. 18). Therefore, the media in Catholic theological reflection are exploited and reduced to being tools of evangelisation, which in Paul VI's apostolic exhortation Evangelii nuntiandi (1975) is defined as "bringing the Good News into all the strata of humanity, and through its influence transforming humanity from within and making it new" (EN 18). Moreover, 'the new evangelization' (a term coined by John Paul II) does not mean re-evangelisation, but the same evangelisation, carried out "with new zeal, new methods and new means of expression" (Lewek 1994; Parzyszek 2010, pp. 135-51). The teachings of the popes after the Second Vatican Council are full of encouragement to use the media and the new media as tools of the new evangelisation, but also appeal to treat the whole media reality as a realm of mission. This is particularly highlighted by the papal addresses for World Communications Days, after which Benedict XVI was referred to as the 'theologian of the digital world' (Spadaro 2013). The 2012 Synod of Bishops, devoted to the New Evangelisation, mentions the media and the new media among the most important contexts and areas of evangelisation activities (Chmielewski 2014, pp. 216-17). Dziewiecki stresses the need to codify the evangelical message according to the structure and language typical of a given media type (Dziewiecki 2010, pp. 59-61). It is also considered necessary for the Church to be present on the Internet, called 'digital/virtual Areopagus' in theological texts (Chyła 2015, p. 73). This also applies to social media, which perform utilitarian functions in the Church, such as: information, education, promotion, evangelisation, formation and community building (Przybysz 2018).

Parallel to theological research, the current studies of religion-media relationships are developing on the basis of social and humanistic disciplines. As Campbell points out, "interdisciplinary investigations into the relationship between religion and new media technologies have evolved into an area of inquiry often referred to as Digital Religion research" (Campbell 2017, p. 15). In addition, studies combining theological and non-theological perspectives should be noted (Cf. McLuhan 2010; Enstedt et al. 2015; González Gaitano 2016; Leśniczak 2018b; Soukup 2019 and many more). The meeting point of these two perspectives is the theology of media and communication (Adamski and Łęcicki 2016a, 2016b), whose precursor is considered to be a Jesuit Enrico Baragli (Baragli 1970).

Referring to non-theological research on the relationship between the media and religion, we especially focused on the media and the Catholic Church, but we are aware that perspectives of another religions, i.e., Protestantism (see Bratosin 2016) may be also very useful. We can also take into account foundational theories that analyse the interactions between media and religion, such as the culturalist tradition, mediatization theory, and the social shaping of technology approach (Peterson 2019, p. 1). Nearly 20 years ago, Hoover (2002, pp. 25-36) wrote about a "culturalist turn in scholarship on media and religion" and outlined a wide panorama of the publications in this research field. Although, the theory of mediatization and its references to religion cannot be omitted, today it may be stated that we are "a society in a process of mediatization" and "the result of this movement and the intense development of digital technologies is the establishment of a new environment where humans, institutions and the diverse social environment interact (Gomes 2016, p. 210). A lot of theoretical and empirical studies scrutinized and operationalized the mediatization as a new paradigm of interpretation and understanding of current societies (see e.g., Tudor and Bratosin 2020, p. 2095; Couldry and Hepp 2013, p. 191). Through the processes of mediatization, religion is becoming 
increasingly embedded in the logic of the media, both in terms of institutional regulations, symbolic content and individual practices (Hjarvard 2008, p. 11). A large part of the changes that are taking place in the perception and understanding of religious concepts happen with the participation of the media (Sierocki 2018, p. 77); what is more, in many countries they are the main source of information and ideas about religion (see Hjarvard 2016).

Paradoxically, the mediatization of religion can be a tool for secularisation. The media are becoming a cultural and social environment which takes over many functions of institutionalised religions and provides its 'followers' with spiritual and moral guidance, satisfying the need for rituals, a sense of community and belonging. (Hjarvard 2011, p. 119). It should be stressed, however, that the mutual relations between the contemporary social transformations of religions and the mediatization processes of ecclesial institution communication need not take the form of automatic determinism, as long as the institution focuses on communicating its own identity and not on gaining/maintaining a high level of popularity among the public (Leśniczak 2019a, p. 237). Nevertheless, there is no denying that as a result of the growing influence of the new media on religion, as well as the development of new technologies and increasing opportunities to satisfy religious needs online, religious communities will have to make choices about what structures should control religious information and how to govern those practices. They will also need to consider how these new forms of online integration should affect the way in which the principles of faith are preached and practised (Campbell 2010, pp. 190-92).

The processes of mediatization and individualisation affect also religious authority, community, ritual, identity and authenticity (ed. Campbell 2013; ed. Hoover 2016; Kołodziejska 2018, pp. 17-24). Digital media have partially overtaken some of the institutional religions' functions such as producing religious or quasi-religious experiences, giving moral guidance and creating a sense of community. In the digital environment, unofficial religious voices can become authoritative actors in specific communities, challenging traditional and institutional authority (Giorgi 2019, pp. 2-3). According to Lövheim and Lundmark (2019, p. 35) "the strong connection between authenticity, vulnerability and interaction with an audience [... ] constructs a form of authority that is seldom self-claimed or formally given, but co-effected and legitimized through the connection between realizing one's own true self and recognizing one's dependency upon, and solidarity with others. Co-effected and relational authority can be forged through strategies of using comments in blogs to build authenticity by performing emotional work, recognizing stigma, or speaking out on behalf of others". Maintaining faith and a religious outlook requires an appropriate social environment and communication activities, which confirm the authenticity of a specific social reality. Direct social interactions are of the utmost importance here, but the growing role of social media encourages the search for manifestations of religiousness in mediated social relations (Sierocki 2018, p. 285). A distinction must be made between religion online and online religion (Helland 2000). The former means static information, lack of interactivity or participation, while the latter means activity, participation, belonging, engagement, including services for activities such as prayer or meditation. Within such platforms, virtual communities are created (Siuda 2010, pp. 31-32). "The presence of religious expression is perceived differently online than offline. The online environment seems to be more democratic, open, and hospitable to individual forms of expression than traditional Catholic settings (e.g., the parish). The Internet becomes a space for voicing courageous opinions which can be both coherent and contradictory to the teachings of the Church. It facilitates personal, individual expressions of faith, shared within a heterogeneous community of believers and nonbelievers" (Kołodziejska 2014, p. 163). Moreover, a study by Brubaker and Haigh among users of religious Facebook profiles showed that there were four main motivations for accessing religious Facebook content: ministering, spiritual enlightenment, religious information, and entertainment. People who frequently use Facebook for posting, liking, commenting, and sharing faith-based content and who are more religious are more likely to minister to others. Many users access Facebook for seeking out and helping others by sharing gospel messages, beliefs, and teachings. Facebook users want to fulfil faith-based information and entertainment needs by accessing faith-based 
posts (Brubaker and Haigh 2017, pp. 1-9). According to them, "Facebook provides an outlet through which religious needs and desires are expressed and fulfilled online" (Brubaker and Haigh 2017, p. 9). Young people in particular, brought up in a mediatised world, may feel a real need to use the Internet for a variety of religious purposes, including access to knowledge and an opportunity to create a community. Research among American students has shown that "the Catholic Church must make a greater effort to make more religious content available online and make it more convenient to obtain it. In addition, the Church must become more aggressive in utilizing new media and sending messages of faith and education about the Church to younger generations" (Nduka and McGuire 2017, pp. 100-1).

With regards to the research on the Catholic media in Poland, the main research done so far has been into their history (Adamski 2008; Łęcicki 2010; Laskowska 2011; Woźniak 2015), the evolution of the Church's teachings on the media (Pokorna-Ignatowicz 2002, 2007; Lewek 2003), the condition of the Catholic media market in Poland and how it functions in the Polish media system (Adamski 2011; Guzek 2016). Leśniczak and Guzek analysed the image of the Catholic Church and its political communication in the secular media (Leśniczak 2016; Leśniczak 2019b and others by the same author; Guzek 2019) and the political communication of the Church through the Catholic media (Leśniczak 2018a).

Research on nationwide Catholic media in Central and Eastern Europe has also been carried out, e.g., in Slovakia (e.g., Rončáková 2018; Gazda and Kulla 2013; Murár 2018; Graca 2020), in Hungary (Andok 2016, 2018; Andok and Vígh 2018) or in Russia (Khroul 2018), but none of them attempted to examine the marketing communication of the Catholic media via social media. The authors of this paper are interested in this "broad and multidisciplinary area of study", encompassing the "relationship between religion, markets, capitalism and consumer culture" (Moberg 2017, p. 2).

\section{Religious Marketing}

Organised and strategic marketing of religious institutions, inspired by the activities of non-profit organisations, appeared in the USA in the 1970s, following the loss of members by Christian churches (Webb et al. 1998, p. 3). However, as early as 1959, James Culliton suggested that the growth of religion was poor due to the churches' inability to adopt marketing rules (Culliton 1959). Nowadays, also thanks to the opportunities offered by the Internet, there are many options for people trying to satisfy their religious needs. Nevertheless, the literature has long ago noted the risk of the over-commercialisation of religion (Moore 1994) and of reducing religious marketing to a tool for obtaining donations from worshippers, which had resulted in a shift towards 'market orientation', understood as an orientation towards the spiritual welfare of members of the community, resulting in their involvement at various levels (Mulyanegara 2015, p. 145). The specific formula of the exchange on which church marketing is based can be treated as commercial but this exchange may be considered in spiritual categories. The Church satisfies the religious needs of its members and requires them to make a spiritual payment-an attitude based on participation in religious practices' living rules resulting from religious doctrine (Gawroński and Majkowska 2018, p. 18).

At present the Catholic Church's approach to religious advertising must take two factors into account. Firstly, it is still difficult to overcome the fears of some religious officials and laymen regarding religion advertising due to fears of desacralisation of the advertised object (Guzek 2013, p. 317). As Wrenn points out, "theologians have been overwhelmingly opposed to any use of marketing by churches, while marketers have turned a blind eye toward their concerns and churned out books and articles on how to do church marketing" (Wrenn 2011, p. 44). Meanwhile, the faithful may expect access to the religious sphere through the media, although as some researchers have noted, this may pose the risk of their religiousness becoming shallower (see Siuda 2010, p. 14). This is probably why religious marketing is often seen as a "necessary evil" (Einstein 2008, p. 207).

Secondly, the specificity of a given country or cultural area must be taken into account. Official Holy See documents or statements from popes are one thing, while the activities of particular churches are another. Much depends on what status the Church has in a given country. In Poland Catholicism 
is (at least officially) a dominant religion, as $93 \%$ of Poles declare themselves as Catholics, of which about $80 \%$ declare themselves to be believers or deep believers. However, only $38 \%$ participate in the Sunday Mass every week, while many Catholics do not fully accept all the rules of conduct that stem from the official doctrine (CBOS 2018; Sadłon et al. 2019). Therefore, there are different opinions of researchers regarding the attitude of the Church in Poland to religious advertising. According to Guzek, the Church in Poland has overcome distrust and fears about the use of advertising for religious issues. The least controversy has always been aroused by advertisements of charity projects, but in the Polish public space there are more and more messages of typically evangelistic and religious nature (Guzek 2013, pp. 317-18). A different, sceptical opinion is expressed by Gawroński \& Majkowska (they believe that the reason is a kind of 'monopoly' of Catholicism) (Gawroński and Majkowska 2018, p. 17), whereas Stepniak's stance can be described as neutral (in his opinion, the Church in Poland, faced with secularisation, is getting ready for the strategic use of religious advertising, although this is happening slowly) (Stępniak 2019, p. 198).

It should be added that in Polish religious advertising the evangelistic context appears very often. However, it is not clear whether this principle applies to the marketing of Catholic magazines, because for them convincing the reader to buy a copy of the magazine is a question of existence. It will be all the more interesting to examine how these magazines perform marketing communication in social media.

\section{Catholic Media in Poland: Legal Issues}

After 1989, in Poland and in other countries of the former Eastern Bloc, there was a shift away from the totalitarian media doctrine, which resulted in the processes of deregulation, elimination of censorship, transition from the concession system to the registration system in the area of the press or the creation of commercial electronic media (radio stations and television channels). In 1989, legal solutions were adopted, which regulated the conditions of the existence and functioning of the Church within the state of Poland, e.g., the Act on the relations between the State and the Catholic Church in the Republic of Poland (Journal of Laws 2013, item 1169, as amended). Articles 48-50 of this legal act give church legal persons a number of rights, including the right to publish the press, to establish their own radio stations and TV channels, and to broadcast the Eucharist and services as well as their own religious-moral programmes in the media (including the public ones). Similar arrangements are contained in the 1993 concordat between the Republic of Poland and the Holy See. Whereas, according to paragraph 3 of Article 25 of the Constitution of the Republic of Poland of 1997, relations between the state and churches and other religious organisations are shaped on the basis of respect for their autonomy and the mutual independence of each other in their own spheres, but also on the cooperation for the benefit of people and the common good.

As far as the functioning of the Catholic media in Poland is concerned, from the legal point of view, they operate under the rules applicable to all media. They are subject to the laws regulating the media market in Poland, primarily the Constitution, the Press Law and the Radio and Television Act. However, from the point of view of the formal criteria of 'catholicity', they are subject to the internal regulations of the Church. The issue is approached in a purely legal sense or in terms of content and attitudes. From a purely legal point of view, the Catholic press is considered to be "publications which, with the permission of the Church authorities, are periodically printed and distributed to the public in order to present a comprehensive portrait of reality, especially of current events and problems of the Church's life and doctrine". (Lepa 1994, p. 4). This rather rigorous definition refers to canon 216 of the Code of Canon Law, which says: "Since they participate in the mission of the Church, all the Christian faithful have the right to promote or sustain apostolic action even by their own undertakings, according to their own state and condition. Nevertheless, no undertaking is to claim the name Catholic without the consent of competent ecclesiastical authority" (CIC 1983).

The Church's acceptance of the Catholic press is expressed in various forms. In the light of the findings of the Second Polish Plenary Synod (1991-1999), media are deemed to be Catholic if they have a Church assistant, appointed by the local bishop. The Church assistant ensures that the Catholic 
media present the holistic teachings of the Gospel and the Church (Evangelisation of Culture and Social Communication Media). In addition, the Church's acceptance of the media may be expressed through the establishment and potential subsidisation of the magazine or the cooperation of the editorial board with the local diocesan bishop (Lepa 1994, p. 4). Guzek defines the Catholic media as "mass and de-massified media (the press, the radio, television, online media) which are guided by the principle of ecclesiality, i.e., they function with the consent or support of the competent Church authority, are disseminated to provide a comprehensive view of reality, moreover they represent journalism based on Catholic principles of communication." (Guzek 2016, p. 24).

However, the provisions of the Second Polish Plenary Synod do not only focus on the legal aspect, but also place requirements upon the Catholic media with regards their content. They should therefore be "a place for spreading the truth, Christian optimism, an approach of love and engaging in an interesting dialogue on educational issues, teaching prayer and Catholic customs, showing ways of achieving holiness in the world, offering attractive role models for children and teenagers, showing opportunities for decent entertainment and leisure." (Evangelisation of Culture and Social Communication Media).

The recognition of Catholic websites or blogs is slightly more complicated. Even the fact that they are maintained by a clergyman, or a person clearly declaring their membership in the Catholic Church, does not make such a blog 'Catholic' in the legal sense (Adamski 2010, p. 105). The postulates of developing a specific 'social media code' for the Church in Poland are becoming more and more popular (Chmielewski et al. 2018). Meanwhile, the media run by the people of the Catholic faith and trying to show events from the point of view of the Catholic doctrine, but without a Church assistant and formal acceptance of the hierarchy, are referred to as the "media of Catholics" (Guzek 2016, p. 24).

With regards to the press market in Poland, one of its characteristic features is the increased specialisation of the magazine sector, with the continuing dominance of women's and opinion-forming magazines. The Polish magazine sector can be divided into segments according to their audiences and topics (women, men, children, teenagers, Catholics, opinion, IT, economy, gossip magazines and TV guides) (Lara 2007). One of them is the Catholic press sector, which in Poland is the largest segment of the Catholic media, with a well-established concentric structure. In 2013 (no current data available), 135 titles of the Catholic mass press were published, with different ranges and degrees of professionalism. Among them were 10 weeklies, 45 monthlies and 31 bimonthly magazines, but not all of them were nationwide (Guzek 2016, pp. 130-31). Several monthlies and bimonthly magazines were addressed to children. It is important to note the current lack of a Catholic daily newspaper ${ }^{1}$. The rather controversial Nasz Dziennik, which has been published since January 1998, cannot be considered a Catholic daily, as it does not have a Catholic assistant (in fact, the publisher has never asked for one) ${ }^{2}$ (Mielczarek 2004, p. 92). In addition, the Tygodnik Powszechny from Kraków (which has a long history of conflict with communist censorship and is considered a magazine of the intellectual Catholic elite), where Karol Wojtyła used to publish, is not currently a Catholic magazine as defined above.

\section{Catholic Press in Poland. Opinion-Forming Weeklies}

The main Catholic weekly opinion magazine in Poland is the Gość Niedzielny. The first issue of Gość Niedzielny (GN) was published in 1923 as the organ of the Apostolic Administration of Silesia. The originator of the creation of the weekly was Rev. August Hlond. Its organiser was Rev. Teodor Kubina. After the Second World War, the current distribution in Silesia was extended to

1 Such a daily newspaper functioned in the years 1993-97-it was called Stowo. Dziennik Katolicki. As a result of a drop in sales and a lack of advertising income, the daily was transformed into a weekly in 1997, and then finally closed (Mielczarek 2004, p. 92).

2 However, in the common understanding, the daily is connected with Father Tadeusz Rydzyk-director of Radio Maryja. Formally, however, the monk from Torun is not the publisher of Nasz Dziennik; the publisher is 'Spes sp. $\mathrm{z}$ o.o.'. (Mielczarek 2004, p. 92). 
Lower Silesia and Opole Silesia. In 1953, after the takeover of the editorial office by Rev. Franciszek Wilczek, the magazine definitely changed the ideological profile and became under the influence of the communist services. After 1956, the control over the magazine was restored by the Katowice bishop curia. An important turn in the history of the magazine took place in 1974 during the times of Rev. Stanisław Tkocz, thanks to whom the magazine about educational values for poorly educated readers turned into a magazine for more demanding recipients. In those days, the Gość Niedzielny was considered a source of independent opinions. In March 1981, the GN became a nationwide weekly (Wilkoń 2018).

Apart from the printed version, the magazine runs the www.gosc.pl website (the main one, together with 22 diocesan mutations) and also owns the Wiara.pl website, devoted to religious issues. It also runs an digital edition (with regional additions), a free mobile application (it has been downloaded more than 10 thousand times on Android, and rated at $4.4^{3}$ ), a newsletter, RSS ${ }^{4}$, the Gość Niedzielny Foundation (https://fundacja.gosc.pl/) as well as channels on social media (IG, TT, YT and FB-it is worth adding here that some regional mutations of the magazine have their own profiles, they are run separately and bring together diverse groups of fans, from about 200 to 4800 people.) The brand of the Gość Niedzielny is Mały Gość Niedzielny for children, which has a printed edition, a website, a digital edition and social media (FB and YT). As one of the few Catholic magazines, the GN is a member of the Press Distribution Control Association-an organization that monitors the volume of press releases and sales in Poland. For a long time now, the GN has been the sales leader among all Polish opinion magazines (including secular ones). ${ }^{5}$

The second largest Catholic weekly opinion magazine in Poland is the Tygodnik Niedziela (TN). The first edition was initiated in 1926 and the magazine was published until the outbreak of the war. The second edition was the years 1945-1953. After Stalin's death, the publishing of TN was stopped again due to the policy of the authorities of the time. The third edition of TN began in 1981. Until 1989, the magazine avoided making unambiguous assessments of political issues and refrained from commenting on current events, but could be considered as opposition to the communist system due to the message of the published content (Dzierżyńska-Mielczarek 2016, pp. 129-30). TN does not belong to the Press Distribution Control Association, all data on circulation and sales in the past came from the publisher and it was not possible to verify them.

In addition to the printed edition (which has 19 diocesan mutations), the following operate under the described brand name: the https://m.niedziela.pl website, the Niezbędnik Katolika website (https://niezbednik.niedziela.pl), the liturgical calendar for the faithful (with its own profile on FB), the Ksiegarnia Niedziela online bookshop (https://ksiegarnia.niedziela.pl), the Niedziela.tv online television (https://tv.niedziela.pl, with its own profile on YouTube), the Niedziela FM online radio (https://fm.niedziela.pl, with its own profile on FB), digital editions (with 19 diocesan issues), a newsletter, the Fundacja Niedziela-Instytut Mediów foundation (http://fundacja.niedziela.pl) and social media (TT, YT and FB-it is worth adding that some printed regional mutations also have their profiles on FB).

Przewodnik Katolicki (PK) also aspires to be a national weekly magazine; founded in 1895, it is the oldest Catholic magazine on the market today. It is published by Drukarnia i Ksiegarnia św. Wojciecha publishing house in Poznań. The weekly does not belong to the Press Distribution Control Association. In addition to the printed edition, the weekly's brand consists of a website (https://www.przewodnik-katolicki.pl/), a digital edition, a mobile application (rating 4.4 and with more than 1000 downloads on Android; no iOS application), a newsletter and social media (TT, IG,

3 There are no data on this subject regarding iOS, but the application has not been updated for at least 12 months, which suggests little interest from the application provider.

4 RSS-Really Simple Syndication; a channel of immediate receiving the most recent news in the Internet.

5 In November 2019, the magazine's sales averaged 105 thousand copies per week (data from the Press Distribution Control Association). 
YT and FB). The PK's brand is Maty Przewodnik Katolicki, with its own website, newsletter and digital edition. The publishing house runs a bookshop and other press publications, which are gathered under other brands.

The Idziemy (I) weekly was initially established as a weekly for the Diocese of Warsaw-Praga ${ }^{6}$. Its brand consists of a printed version, a website (http://idziemy.pl/dynamic/o-nas), digital editions and social media (Pinterest, Google+, TT and FB). Currently, it is also distributed in the churches of the Archdiocese of Warsaw and the Archdiocese of Gdańsk.

The last of the analysed magazines, Tygodnik Rodzin Katolickich Źródło (TRKŹ), offers its readers a printed edition, the http://zrodlo.krakow.pl/ website and social media (FB, YT). It is published by the Fundacja Źródło foundation in Kraków. The first issue was published on 5 January 1992, still in black and white print. Since 1996, the magazine has been published in colour ${ }^{7}$.

The aforementioned titles are available not only in churches but also in nationwide distribution networks and outlets throughout Poland. Their undoubted advantage, without which they would not build their current position, is that they cooperate closely with diocesan bishops and that they print diocesan inserts (attached to the main spine). At this point it is worth explaining that diocesan mutations were often created by transforming former diocesan magazines into a local insert for the main magazine. Such a policy was enforced by both the market rules and the provisions of the Polish Bishops' Conference on the consolidation of diocesan press centres around the largest national weeklies (Dzierżyńska-Mielczarek 2016).

Another factor that gives the discussed segment of press titles an advantage over the secular press is the additional distribution channel, i.e., Sunday sales in churches. Basically, each of the Catholic press titles can also be purchased in secular outlets, but many readers buy Catholic press after the Sunday Eucharist. The way this form of distribution is accounted for depends on agreements between bishops and editorial offices, but this additional distribution channel still undoubtedly increases the sales of the Catholic press in Poland. Perhaps this is also the reason why the editors of some magazines are reluctant to reveal the details on the circulation and sales data.

Despite their advantages in the area of distribution, Catholic weeklies in Poland also have to face the challenges of media convergence and the processes of readers' transition from the printed press to the electronic press. One of the dimensions of convergence is communication through social media (Siuda 2010; Guzek 2012), practiced by all printed, audio-visual and digital media.

\section{The Use of Social Media by Traditional Media}

In 2012, Olszański defined four basic areas of functioning of media entities in social media: informing, involving the audience, collecting information for the benefit of their own service, and promotion (Olszański 2012, p. 226). Today, the marriage between tradition and the digital world is even stronger: according to Bell (2018), "newsrooms are increasingly oriented toward understanding and leveraging platforms as part of finding a sustainable future", and in spite of "negative rhetoric and sentiment in newsrooms toward technology companies, there is a rapid and ongoing merging in the functions of publishers and platforms." (Bell 2018, p. 3) Some researchers even believe that the discussed platforms are "in the process of changing how news is produced, disseminated, and discussed" (Nielsen and Schrøder 2014, p. 472). Such strong stances can be regarded as the result of the rapid inclusion of social networking sites in the strategy for the development of traditional media, including their content, promotion and distribution (Szews 2014, p. 72; Messner et al. 2012).

Looking at the uniqueness of media products (Jupowicz-Ginalska 2010, pp. 55-56), one can risk a statement that the use of social media by the media also remains unique. For years the phrase "medium

6 Since 1992, the capital city of Warsaw has been divided into two separate dioceses: the Archdiocese of Warsaw and the Diocese of Warsaw-Praga. A natural border is the Vistula River, which flows through Warsaw, dividing it into two parts.

7 http://zrodlo.krakow.pl/o-nas/. 
is the message" (McLuhan 1998, p. 39) has referred to the press, radio and television. Nowadays, it should apply to all the entities operating online, including those that cannot be described as media broadcasters. In other words, messages are created by producers of goods not associated with the media industry, such as clothes and food. However, this fact does not mean that they become media, but that they benefit from the democratisation of communication, making themselves somewhat independent of the media, or competing with them for the attention of the audience. Currently it is even believed that social media have become an undoubted rival of the press and other traditional media in fulfilling the informational function. This competition is definitely won by social media among the generation of digital natives (Sawicka 2019). It is therefore obvious to publishers/senders that, in the face of increasing competitiveness and changes in content consumption, their portfolios should be expanded to include modern forms of reaching out to the recipients/potential consumers. This is because publishers know that "the new media user is after all a potential customer" (Masłyk 2018). As a result, the media message multiplies and the multi-channel nature of its distribution is stretched between the different media that make up a complementary story about a media brand and its content. The significance of distribution in this context was described by Napoli (2019), while Neuberger et al. (2019) suggested a classification of the use of social media in journalism, dividing it into five general dimensions and 24 specific uses.

Today, social media is a permanent part of the contemporary media ecosystem, which is based on publishing multiplatforms (Ju et al. 2013, p. 13; Alejandro 2010, p. 38). Thus, social media participate in building media brands (Jupowicz-Ginalska 2017, p. 856; Jupowicz-Ginalska 2019, p. 70; Hedman and Djerf-Pierre 2013, p. 4). Sellas and Bonini summed it up neatly, believing that "while presenters and journalists are the masters of a radio's relationship with its audience, Social Media managers are the masters of this relationship online. All of them ( ... contribute to the brand management of their radio station, embodying the station's values"' (Sellas and Bonini 2014, p. 78). Going further, social media, performing a marketing function (content distribution, cooperation with business partners, redirection to paid paywalls, intensive self-promotion, permanent contact with the audiences), also offer an intermediary (Nowak 2012, p. 25), creating or multiplying messages which have previously been published. This is done, for example, by publishing quotes from radio/television programmes, titles/fragments of journalistic material and links. Social media are therefore a kind of complement: something McLuhan would perhaps describe as "media is the multiple message", while today's media observers describe it as "an extension of media life". (Todorczuk 2013) or the "soul of the brand" (Berezowski 2014).

Broadcasters and media publishers nowadays use all the features offered by social networking platforms. As Bell stated, the "vast majority of organizations have taken steps to adapt to this social-mediated news environment." (Bell 2018, p. 5). It is worth emphasising that they do it intensively and regularly, with the larger ones using multiple social media platforms simultaneously (with Facebook at the forefront), while the smaller ones choose only Facebook and Twitter (6-7). Interestingly, the posting takes place in a continuous and ongoing mode. This is unsurprising as, after all, the traditional form of communication is constantly being updated; therefore, since it is changing, the profile in social media must also be modified. This speed of reaction, faster than TV or print, the ability to create opinions, to initiate discussions and to reach out with a convergent, informational and promotional post, determine the importance of social media in the daily practice of the media. It is so large that traditional media willingly expose profiles in their everyday, 'non-social' content, e.g., by referring to their websites, quotations, publishing ongoing comments of Internet users about the TV program while it is running, or plug-ins on websites. Thus, a characteristic feature is the growing cross-media character of media content, with its "multi-profiling" at the same time: social media channels are run by media corporations, specific media, radio and television programmes and brand ambassadors (journalists, presenters, etc.). Therefore, taking into account the way social media are used by the media, it can be concluded that it goes beyond the standard social media marketing 
activities of other industries, where indeed, there is information, community building, promotion, but without dealing with the product content.

\section{Research Questions, Hypotheses, Methodology—Description of the Project}

Much of the previous research in Poland and Europe referred to the mediatization of religion, but none of them-according to the authors' best knowledge-attempted to complexly examine the marketing communication of the Catholic media via social media. Therefore, it may be stated that there are some serious academic gaps in the literature on the relations between religion, traditional media, social media and marketing communication. An attempt to close these gaps is the main premise for starting the aforementioned research project, which is presented here (for better optimization of works in the next parts of the cycle).

The general research questions for the whole cycle are: what marketing functions do the profiles of selected Catholic media perform? How do users, especially those who are religiously involved and treat social media as a "the digital Areopagus", react to this style of communication? The authors of the cycle therefore focused on the implementation of social media platforms in the process of creating a media product, distributing its content, potential content valuation and brand communication, aimed at building relations with the environment and self-promotion. Due to the multithreaded nature of the issues, auxiliary detailed research questions $(\mathrm{RQ})$ were formulated:

- RQ1: Are the social profiles of Catholic weeklies emanations of their media brands and the carriers (additional channels of distribution) of their content, or, apart from marketing, do they have additional functions of evangelising, apology or community-forming?

- RQ2: Is the content of these profiles original or rather secondary to the content published in other distribution channels of these magazines (such as websites)?

- RQ3: Are the profiles managed regularly, according to a certain schedule? How large is post reach and is there a noticeable connection between their topics and the reactions of the audience? Do people who post comments accept the convention of the profile as a place of marketing the weekly's content, or do they treat the profiles as places for expressing religious feelings, evangelisation, apologetic-polemic activities?

- RQ4: Do the profile administrators interact with those who comment? How do they react to potential polemic, apologetic, evangelistic behaviour of the users?

- RQ5: Do the administrators use the features provided by the social networking platforms? What is the scale of using the profiles for self-promotional purposes?

- RQ6: Which type of posts (video, graphic, text, mixed) are the most common?

- RQ7: What are the topics of the posts on the profiles? How do the issues related to self-promotion compare in this context?

- RQ8: Are there any differences and similarities between the marketing methods of social media used by the Catholic weeklies?

- RQ9: Is there a well-considered concept for managing the profiles, or is it a necessity to be treated as a burden due to the lack of a clear concept and strategy?

- RQ10: How does the press, associated with the most traditional media category, handle the marketing potential of social networking platforms?

The working hypothesis is this: the editors of nationwide, opinion-forming Catholic weeklies do not fully exploit the marketing potential of social media, so their profiles are not managed in a professional manner, which results in a small number of interactions and low post reach. Thus, the functions of the profiles are limited to completing the main communication channel, which is the printed weekly and its website.

To answer the research questions and verify the hypothesis, the authors used two research methods:

- extensive literature review -in each of the following papers the presentation of the empirical research was preceded by a literature review referring to firstly, the specific social media 
platform (its popularity in Poland and what research threads it appears in), and secondly-its implementation in the marketing communication activities of the traditional media (especially press). The research took a descriptive form.

- Case studies of the social media profiles (accounts) of nationwide, Catholic opinion-forming weeklies in Poland-in each of the following papers the presentation, description and comparison of these profiles (referring to the specific social media platform) is included. It must be stated that all weeklies that were mentioned earlier were selected: Gość Niedzielny, Niedziela, Przewodnik Katolicki, Idziemy and Tygodnik Rodzin Katolickich Źródło. The presented and then compared data included for example the number of fans/followers/subscribers, visual presentation of the profiles, references to other social media ran by the analysed weeklies, contact details, ratings issued by fans, or elements of content commercialisation.

- Quantitative, qualitative and comparative analyses of the content of the posts published on these profiles-in each of the following papers the presentation of the empirical research refers separately to Facebook (second paper), Twitter (third paper), and Instagram and Youtube (fourth paper). In these cases, the content of the posts made by administrators, their form, as well as the reactions of Internet users, were taken into account).

Referring to the content analysis it should be added that the empirical research, carried out between 18th and 24th November 2019, was based on two-stage calculations, made with the use of extended categorisation keys. The first stage of coding involved the aggregation of data on the time of publication, the type of posts (e.g., text, video, mixed), the number and form of reactions received (characteristic of each platform, e.g., 'angry' for FB, and 'hearts' for IG; what was taken into account was shares, and whether and how the medium responded to comments from Internet users), the scope in which the features offered by the platforms were used, the origin of the posts (original or borrowed), the geography of the posts (i.e., which areas of the world it concerned) and their belonging to thematic macro-categories (such as religion, society, politics, economy, culture, sport, law and self-image). Detailed data on this subject are presented in Table 1.

Table 1. Content coding schedule-Stage I.

\begin{tabular}{|c|c|c|c|c|c|c|}
\hline Coding Subject & Facebook & Twitter & Instagram & YouTube & $\begin{array}{c}\text { Answering } \\
\text { to Research } \\
\text { Question }\end{array}$ & Explanation \\
\hline $\begin{array}{l}\text { Who runs the } \\
\text { profile on a given } \\
\text { social medium }\end{array}$ & $\begin{array}{l}\text { All the } \\
\text { selected } \\
\text { weeklies }\end{array}$ & $\begin{array}{c}\text { Gość } \\
\text { Niedzielny, } \\
\text { Tygodnik } \\
\text { Niedziela, } \\
\text { Przewodnik } \\
\text { Katolicki }\end{array}$ & $\begin{array}{c}\text { Gość } \\
\text { Niedzielny, } \\
\text { Tygodnik } \\
\text { Niedziela, } \\
\text { Przewodnik } \\
\text { Katolicki }\end{array}$ & $\begin{array}{c}\text { Gość Niedzielny, } \\
\text { Tygodnik } \\
\text { Niedziela, } \\
\text { Przewodnik } \\
\text { Katolicki, } \\
\text { Tygodnik Rodzin } \\
\text { Katolickich Źródto }\end{array}$ & - & $\begin{array}{l}\text { Components of the } \\
\text { research sample }\end{array}$ \\
\hline Date of post & $x$ & $\mathrm{x}$ & $x$ & $x$ & RQ3 & $\begin{array}{l}\text { Allows to specify the } \\
\text { systematics of the } \\
\text { profile management }\end{array}$ \\
\hline Time of post & $x$ & $x$ & $x$ & $x$ & RQ3 & As above \\
\hline $\begin{array}{c}\text { Format of post } \\
\text { (e.g., text, graphic, } \\
\text { video, link, mixed) }\end{array}$ & $\mathrm{x}$ & $\mathrm{x}$ & $x$ & $x$ & $\begin{array}{l}\text { RQ1, RQ5, } \\
\text { RQ6: }\end{array}$ & $\begin{array}{l}\text { Allows to specify the } \\
\text { relation (visual, textual) } \\
\text { between social media } \\
\text { profiles and media } \\
\text { brands; allows to } \\
\text { specify the proficiency } \\
\text { in creating different } \\
\text { types of posts }\end{array}$ \\
\hline $\begin{array}{l}\text { Total number of } \\
\text { reactions }\end{array}$ & $\mathrm{x}$ & $\mathrm{x}$ & $x$ & $\mathrm{x}$ & RQ3 & $\begin{array}{l}\text { Allows to specify the } \\
\text { post reach and } \\
\text { connection between } \\
\text { posts' topics and the } \\
\text { reactions of the } \\
\text { audience }\end{array}$ \\
\hline
\end{tabular}


Table 1. Cont.

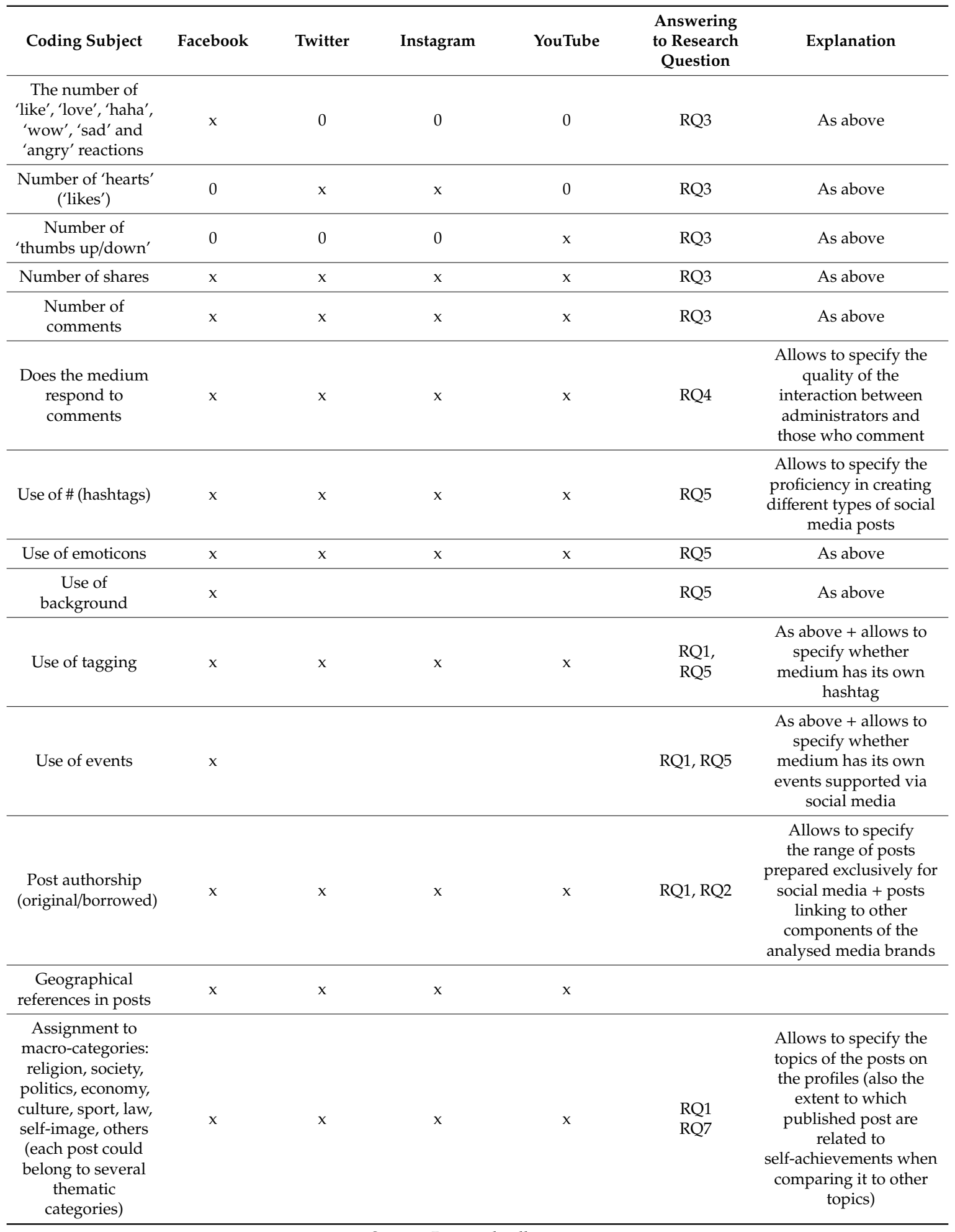

Source: Personal collection.

In the second stage of coding, each of the thematic macro-categories was broken down into more specific categories (Table 2), which meant that each selected social networking site was examined according to 61 thematic threads. Additionally, the aggregated posts were analysed in the context of the text (e.g., emotional tone) and visual aspects (e.g., specificity of illustrations, their emotionality). It is worth adding that the breakdown into categories mainly pursued the first and seventh research 
goal-especially in the area indicating the thematic diversity of self-image/self-achievements posts (it enabled to specify what was promoted and how often). As it can be seen, other macro-categories have also been broken down into categories, but the results of their analyses are not part of this cycle of articles because they are outside its scope.

Table 2. Content coding schedule-Stage II.

\begin{tabular}{|c|c|}
\hline Macrocategory & Categories \\
\hline religion & $\begin{array}{l}\text { Faith, homosexuality in the Catholic Church, church events and celebrations, the Ten } \\
\text { Commandments, history and important figures of the Catholic Church, moral scandals } \\
\text { in the Catholic Church, other. }\end{array}$ \\
\hline society & $\begin{array}{l}\text { Upbringing/education, health, migration, LGBT/gender, } \\
\text { euthanasia/abortion/contraconception, patriotism, non-corporate media, moral } \\
\text { scandals, history, other. }\end{array}$ \\
\hline politics & $\begin{array}{l}\text { Elections, activities of the government/the ruling party, activities of the president, } \\
\text { activities of the opposition, EU activities/relations with the EU, US activities/relations } \\
\text { with the US, activities of other countries/relations with other countries. }\end{array}$ \\
\hline economy & $\begin{array}{l}\text { State budget, financial condition of Poland, financial condition of the EU, condition of } \\
\text { the global economy, the euro currency, social benefits, new taxes, other. }\end{array}$ \\
\hline culture & $\begin{array}{l}\text { Events, books, films, theatre, painting and sculpture, music, people of culture, cultural } \\
\text { laws, other. }\end{array}$ \\
\hline sport & Events, sports promotion, athletes, sports laws, other. \\
\hline law & $\begin{array}{l}\text { Legislation, Court of Justice of the European Union (CJEU), judges, Polish Constitution, } \\
\text { criminal and civil cases, other. }\end{array}$ \\
\hline $\begin{array}{l}\text { the magazine's own } \\
\text { achievements }\end{array}$ & $\begin{array}{l}\text { Events (including patronage), market success, success/information about employees, } \\
\text { next issue of the magazine, insert to the magazine, patronage granted, social campaign, } \\
\text { links from the magazine's own medium, other. }\end{array}$ \\
\hline
\end{tabular}

Source: Personal collection.

Tables 1 and 2 show the close links between the research questions (No. 1-7) and content analysis. The research questions $8-10$, because of their summarizing nature, were answered in the last paper, which is to compare all the social media activities of studied Catholic weeklies.

It should be stressed that in order to obtain comparable data, the analysis of all social media was carried out using the same codification key, taking into account the specifics of individual social media and each of the authors of the cycle was in charge of coding posts on the profile that was assigned to them (one person for FB, one for TT, one for IG and YT). To ensure the reliability of the test results, the coded information was cross-checked by other researchers. In case of any doubts, unclear data were discussed and coded together.

\section{Research Limitation and Difficulties}

The contemporary reality of religious institutions, including the associated media, determines the necessity for them to be present on the Internet and social media.

As the process of losing the faithful is ongoing and the media audiences are being saturated with recipients immersed in the online world, it is essential—not only for the sake of evangelisation, but above all for the sake of business-to make professional use of the tools available to establish and maintain relationships with the faithful.

Given the state of research so far, it is not completely clear how to classify Catholic media profiles on social networking sites. On the one hand, the media activity of the Church is typically evangelistic in nature, but on the other hand it takes place in typically secular conditions. The evangelising role of the Catholic media cannot be separated from the opinion-forming function, and the media themselves must resort to typical marketing activities in order to gain and maintain the audience. This also applies to the category of social broadcasters, specific to the Polish media market, i.e., radio or television 
broadcasters who cannot show commercials, but may be maintained by voluntary contributions from their listeners/viewers (Wilk 2018, pp. 16-19). In order to encourage their listeners/viewers to make voluntary contributions, social broadcasters need to build a community with them, to trigger their engagement-hence, it is difficult to definitively separate marketing and evangelistic activities.

It is also important to remember about the perspective of the recipients. Their involvement along with the relationship between supporting Catholic media and the principles of faith can often prevent them from being rational and cautious about the content offered by Catholic broadcasters and publishers in social media. In turn, from the editorial point of view, the ideal recipient is someone who, in response to the given content, embraces it and uses it to deepen their faith, who avoids aggressive and xenophobic behaviours, and from the purely material point of view, supports these media financially, either by buying a copy of the magazine, by making a donation for its activities, or by buying an advertisement. Therefore, it seems that the ultimate, practical aim of the research project presented here is not only to answer theoretical questions and to broaden the knowledge on the tools of religion mediatization, but also-as indicated at the beginning-to develop recommendations for publishers and broadcasters of Catholic media in Poland in order to professionalise the message in social media, which will be beneficial for both the broadcasters and the audiences.

\section{Conclusions}

This paper is the first opening publication of the cycle of five articles. In the following parts the authors will present the research results of the empirical study on the communication of the Polish Catholic Weeklies on social media platforms. Therefore, this paper was devoted to presentation of the theoretical and methodological framework of the whole research project, as well as the review of the research approaches at the intersection of media and religious studies. It was observed, that the majority of studies on the Catholic media were dominated by the theological approach, very often focusing on treating media as a tool of evangelisation. At the same time, the marketing perspective-which is up-to-date in the contemporary world-was being overlooked. On the other hand, a lot of papers referring to the marketing of religion were grounded in the Protestant perspective.

One of the crucial parts of this paper is also the presentation of the legal framework of operating religious media in Poland, which is typical for Eastern European countries. The transition process of the structure of the media system initiated in 1989 is still in progress, as well as is social and cultural change, which also influences the religiosity of Poles. The authors also defined the concept of 'catholic media' in Poland and presented the range of catholic media in Poland (especially catholic weeklies), including their shortened history and contemporary status. There were following titles: Gość Niedzielny, Niedziela, Przewodnik Katolicki, Idziemy oraz Źródło.

The last part of this article concerned the detailed methodology of the research project, including research questions and hypothesis. This part is common for all the empirical articles in the cycle, which addressed this theoretical framework, methodological approach and techniques. It also included the description of the specific difficulties that should be taken into account when differing marketing and evangelisation communication by the potential receivers, often treating Catholic-media profiles on the social media platforms as the place for present evangelical and not promotional content.

Author Contributions: All authors shared the work on conceptualization, methodology, validation, formal analysis, investigation, resources, data curation and writing process. All authors have read and agreed to the published version of the manuscript.

Funding: This research received no external funding.

Acknowledgments: This research received no administrative and technical support.

Conflicts of Interest: The authors declare no conflict of interest. 


\section{References}

Adamski, Andrzej. 2008. Kapłan i Dziennikarz. Warszawa: Wydawnictwo Sióstr Loretanek.

Adamski, Andrzej. 2010. Ksiądz w blogosferze. Kultura-Media-Teologia 2: 99-111. [CrossRef]

Adamski, Andrzej. 2011. Kościół ma “dobra prasę”? Stan prasy katolickiej w Polsce. In Media i Kościót. Polityka Informacyjna Kościoła. Edited by M. Przybysz and K. Marcyński. Warszawa: Elipsa.

Adamski, Andrzej. 2013. Refleksja teologiczna nad natura Kościoła rzymskokatolickiego a jego wizerunek medialny. In Dialog Wiary z Nauką i Kulturą. Edited by B. Bogołębska and M. Worsowicz. Łódź: Wydawnictwo Uniwersytetu Łódzkiego, pp. 41-60.

Adamski, Andrzej, and Grzegorz Łęcicki. 2016a. Theology and media studies: Interdisciplinarity as a platform for joint reflection on the media. Studia Medioznawcze 1: 11-19.

Adamski, Andrzej, and Grzegorz Łęcicki. 2016b. Teologia mediów i komunikacji-Na styku nauk o mediach oraz nauk teologicznych. Studia Medioznawcze 2: 11-21.

Alejandro, Jennifer. 2010. Journalism in the Age of Social Media. Reuters Institute Fellowship Paper for the Study of Journalism; University of Oxford. Available online: https://reutersinstitute.politics.ox.ac.uk/our-research/ journalism-age-social-media (accessed on 18 February 2020).

Andok, Mónika. 2016. Church, People and Media in Hungary. In Seekers or Dwellers? Social Character of Religion in Hungary. Edited by Zsuzsanna Bögre. Washington, DC: The Council for Research in Values and Philosophy, pp. 4-26.

Andok, Mónika. 2018. Media, Religion and Public Sphere: International Trends and Hungarian Researches. KOME-An International Journal of Pure Communication Inquiry 6: 16-31. [CrossRef]

Andok, Mónika, and Fanni Vígh. 2018. Religious communities' digital media use: A Hungarian case study. In Believe in Technology: Mediatization of the Future and the Future of Mediatization. Edited by M. A. Tudor and S. Bratosin. Les Arcs: IARSIC France, pp. 378-92.

Baragli, Enrico. 1970. Verso una teologia degli strumenti di comunicazione soziale. La Civilta Cattolica 121: 141-50.

Bell, E. 2018. Executive Summary. In Friend \& Foe: The Platform Press at the Heart of Journalism. Edited by Nushin Rashidian, Peter D. Brown, Elizabeth Hansen, Emily J. Bell, Jonathan R. Albright and A. Hartstone. New York: Tow Center for Digital Journalism-Columbia Journalism School, Available online: https://www.cjr.org/tow_center_reports/the-platform-press-at-the-heart-of-journalism.php (accessed on 18 February 2020).

Berezowski, Oskar. 2014. Pinokio w Social Media, Czyli Media Tradycyjne. Available online: https://napoleoncat.com/ pl/blog/pinokio-w-social-media-czyli-media-tradycyjne (accessed on 20 January 2020).

Bratosin, Stefan. 2016. La médialisation du religieux dans la théorie du post néo-protestantisme. Social Compass 63 : 405-20. [CrossRef]

Brubaker, Pamela Jo, and Michel M. Haigh. 2017. The Religious Facebook Experience: Uses and Gratifications of Faith-Based Content. Social Media + Society 3. [CrossRef]

Campbell, Heidi A. 2010. When Religion Meets New Media. London and New York: Routledge.

Campbell, Heidi A., ed. 2013. Digital Religion. Understanding Religious Practice in New Media Worlds. New York: Routledge.

Campbell, Heidi A. 2017. Surveying theoretical approaches within digital religion studies. New Media E Society 19: 15-24. [CrossRef]

Centrum Badania Opinii Społecznej. 2018. Religijność Polaków i Ocena Sytuacji Kościoła katolickiego-Komunikat z Badań. Warszawa: CBOS, vol. 147.

Chmielewski, Mirosław. 2014. Media społecznościowe jako narzędzia nowej ewangelizacji. Świat i Słowo 1: 213-29.

Chmielewski, Mirosław, Izabela Dorma, and Rafał Kusiak. 2018. “Kodeks" social media dla Kościoła katolickiego w Polsce. Biuletyn Edukacji Medialnej 1: 146-69.

Chyła, Janusz. 2015. Ewangelizacja cyfrowego kontynentu. Kultura-Media-Teologia 3: 67-79. [CrossRef]

Catholic Church. 1983. The Code of Canon Law: In English Translation. London: Collins.

Couldry, Nick, and Andreas Hepp. 2013. Conceptualizing Mediatization: Contexts, Traditions, Arguments. Communication Theory 23: 191-202. [CrossRef]

Culliton, James W. 1959. A Marketing Analysis of Religion. Business Horizons 2: 85-92. [CrossRef]

Dzierżyńska-Mielczarek, Jolanta. 2016. Tygodnik Katolicki “Niedziela” w latach 1981-2014. Koncepcja wydawnicza i miejsce w polskim systemie medialnym. Kultura-Media-Teologia 1: 127-43. [CrossRef] 
Dziewiecki, Marek. 2010. Ewangelizacja w kulturze ponowoczesnej i medialnej. Kultura-Media-Teologia 1: 49-64. [CrossRef]

Einstein, Mara. 2008. Brands of Faith. Marketing Religion in a Commercial Age. New York: Routledge.

Enstedt, Daniel, Göran Larsson, and Enzo Pace, eds. 2015. Religion and Internet. Annual Review of the Sociology of Religion. Leiden: Brill.

Gawroński, Sławomir, and Ilona Majkowska. 2018. Marketing Communication of the Catholic Church-A Sign of the Times or Profanation of the Sacred? Studia Humana 7: 15-23. [CrossRef]

Gazda, Imrich, and Albert Kulla. 2013. The Use of New Media in the Catholic Church. Informatologia 46: 232-39.

Giorgi, Alberta. 2019. Mediatized Catholicism-Minority Voices and Religious Authority in the Digital Sphere. Religions 10: 463. [CrossRef]

Gomes, Pedro G. 2016. Mediatization: A concept, multiple voices. ESSACHESS. Journal for Communication Studies 9: 197-212.

González Gaitano, Norbert. 2016. Public opinion in the Church. A communicative and ecclesiological reflection. Church, Communication and Culture 1: 173-205. [CrossRef]

Graca, Martin. 2020. Rate of use of social network in Catholic media in Slovakia. European Journal of Science and Theology 16: 113-18.

Günther, Elisabeth, and Emese Domahidi. 2017. What Communication Scholars Write About: An Analysys of 80 Years of Research in High-Impact Journals. International Journal of Communication 11: 3051-71.

Guzek, Damian. 2012. Konwergencja mediów katolickich w Polsce. In Konwergencja Mediów Masowych i Jej Skutki dla Wspótczesnego Dziennikarstwa. Part 2. Edited by Marian Gierula, Zbigniew Oniszczuk, Patrycja Szostok and Mirosława Wielopolska-Szymura. Katowice: Wydawnictwo Uniwersytetu Ślaskiego, pp. 227-40.

Guzek, Damian. 2013. Reklama w działaniach instytucji religijnych w Polsce. Chorzowskie Studia Polityczne 6: 311-26.

Guzek, Damian. 2016. Media katolickie w Polskim Systemie Medialnym. Torun: Wydawnictwo Adam Marszałek.

Guzek, Damian. 2019. The Church-State Relationship in Polish Media: Combining the Grounded Theory and Intermedia Agenda-Setting at the Network Level. Polish Sociological Review 208: 439-57. [CrossRef]

Hedman, Ulrika, and Monika Djerf-Pierre. 2013. The social journalist: Embracing the social media life or creating a new digital divide? Digital Journalism 1: 368-85. [CrossRef]

Helland, Christopher. 2000. Online Religion/Religion Online and Virtual Communities. In Religion on the Internet: Research Prospects and Promises. Edited by Jeffrey K. Hadden and Douglas E. Cowan. Amsterdam, London and New York: JAIPress/Elsevier Science, pp. 205-33.

Hjarvard, Stig. 2008. The mediatization of religion. A theory of the media as agents of religious change. Nordic Journal of Media Studies 6: 9-26. [CrossRef]

Hjarvard, Stig. 2011. The mediatization of religion: Theorising religion, media and social change. Culture and Religion: An Interdisciplinary Journal 12: 119-35. [CrossRef]

Hjarvard, Stig. 2016. Mediatization and the changing authority of religion. Media, Culture E Society 38: 8-17. [CrossRef]

Hoover, Stewart. 1997. Media and the construction of the religious public sphere. In Rethinking Media, Religion, and Culture. Edited by Stewart Hoover and Knut Lundby. London: Sage, pp. 283-97.

Hoover, Stewart. 2002. The Culturalist Turn in Scholarship on Media and Religion. Journal of Media and Religion 1: 25-36. [CrossRef]

Hoover, Stewart. 2011. Media and the imagination of religion in contemporary global culture. European Journal of Cultural Studies 14: 610-25. [CrossRef]

Hoover, Stewart, ed. 2016. The Media and Religious Authority. University Park: Penn State University Press.

Ju, Alice, Sun Ho Jeong, and Hsiang Iris Chyi. 2013. Will social media save newspapers? Journalism Practice 8: 1-17. [CrossRef]

Jupowicz-Ginalska, Anna. 2010. Marketing Medialny. Warszawa: Wydawnictwo DIFIN.

Jupowicz-Ginalska, Anna. 2017. Marka Empire jako przykład multiplatformy medialnej—Studium przypadku. Zeszyty Prasoznawcze 4: 845-65. [CrossRef] 
Jupowicz-Ginalska, Anna. 2019. FOMO, Brands and Consumers-About the Reactions of Polish Internet Users to the Activities of Brands in Social Media (Based on CAWI Representative Research). Social Communication Online Journal 2: 69-84. [CrossRef]

Khroul, Victor. 2018. Religious Media Dynamics in Russia after 'Perestroika' (1991-2017). Kultura-Media-Teologia 2: 39-62. [CrossRef]

Kołodziejska, Marta. 2014. Religion on Catholic internet forums in Poland. A memory mediated. Nordic Journal of Religion and Society 27: 151-66.

Kołodziejska, Marta. 2018. Online Catholic Communities. Community, Authority, and Religious Individualisation. New York: Routledge.

Lara, Ania. 2007. The Polish Media Landscape. In European Media Governance: National and Regional Dimensions. Edited by Georgios Terzis. Bristol and Chicago: Intellect Books, pp. 399-410.

Laskowska, Małgorzata. 2011. Ks. Stefan Wyszyński-Dziennikarz i Redaktor (1924-1946). Toruń: Wydawnictwo Adam Marszałek.

Lepa, Adam. 1994. Katalog prasy katolickiej w Polsce. Łódź: Archidiecezjalne Wydawnictwo Łódzkie.

Leśniczak, Rafał. 2016. The communicative role of the Catholic Church in Poland in the 2015 presidential election and its perception by the public. Church, Communication and Culture 1: 1-18.

Leśniczak, Rafał. 2018a. Polish Catholic press and political communication of the Church on the basis of the 2000-2015 presidential election. Political Preferences 18: 37-56. [CrossRef]

Leśniczak, Rafał. 2018b. Teologia środków społecznego przekazu i nauki o mediach jako dwie perspektywy badań wizerunku medialnego przywódców religijnych Kościoła katolickiego-Kilka uwag do dyskusji. In Teologia Środków Społecznego Przekazu w Naukach o Mediach. Edited by Jerzy Olędzki. Warszawa: Wydawnictwo UKSW.

Leśniczak, Rafał. 2019a. Mediatization of Institutional Communication of the Catholic Church. Reflections on the Margins of the Migration Crisis. Studia Medioznawcze 3: 237-46. [CrossRef]

Leśniczak, Rafał. 2019b. Wizerunek Zgromadzeń Zakonnych w Prasie Polskiej (2013-2016). Warszawa: Wydawnictwo UKSW. Lewek, Antoni. 1994. Idea i sens nowej ewangelizacji. Studia Theologica Varsaviensia 2: 45-107.

Lewek, Antoni. 2003. Podstawy Edukacji Medialnej i Dziennikarskiej. Warszawa: Wydawnictwo UKSW.

Lövheim, Mia, and Evelina Lundmark. 2019. Gender, Religion and Authority in Digital Media. ESSACHESS. Journal for Communication Studies 12: 23-38.

Łęcicki, Grzegorz. 2010. Media katolickie w III Rzeczypospolitej (1989-2009). Kultura-Media-Teologia 2: 112-22. [CrossRef]

Masłyk, Justyna. 2018. Using the New Media by Companies from the SME Sector in Podkarpackie Province. Social Communication Online Journal 2: 85-95. [CrossRef]

McLuhan, Marshall. 1998. Zrozumieć Media. Warszawa: Wydawnictwa Naukowo-Techniczne.

McLuhan, Marshall. 2010. The Medium and the Light. Eugene: Wipf \& Stock.

Merton, Robert. 2002. Teoria Socjologiczna i Struktura Społeczna. Warszawa: Wydawnictwo Naukowe PWN.

Messner, Marcus, Maureen Linke, and Asriel Eford. 2012. Shoveling Tweets: An Analysis of the Microblogging Engagement of Traditional News Organizations. ISOJ Journal 2: 76-90.

Mielczarek, Tomasz. 2004. Prasa Kościoła katolickiego w Polsce w latach 1989-2004. In Media wyznaniowe w Polsce 1989-2004. Edited by Elżbieta Kossewska and Janusz W. Adamowski. Warszawa: ASPRA-JR, pp. 89-96.

Moberg, Marcus. 2017. Church, Market, and Media: A Discursive Approach to Institutional Religious Change. London, Oxford, New York, New Delhi and Sydney: Bloomsbury Publishing.

Moore, Laurence R. 1994. Selling God: American Religion in the Marketplace of Culture. New York and Oxford: Oxford University Press.

Mulyanegara, Riza Cassidy. 2015. Church Marketing: An Investigation of the Role of Market Orientation in Church Participation. In Proceedings of the 2008 Academy of Marketing Science (AMS) Annual Conference. Developments in Marketing Science. Edited by Robinson Leroy Jr. Cham: Springer, pp. 143-47.

Murár, Peter. 2018. Slovak catholic media on Facebook: Do they follow recent trends? In ESRARC 2018. 10th European Symposium on Religious Art, Restoration \& Conservation Proceedings Book. Edited by Slavomir Magál, Dáša Mendelová, Dana Petranová and Nicolae Apostolescu. Torino: Kermes Books, pp. 207-9.

Napoli, Philip M. 2019. Social Media and the Public Interest: Media Regulation in the Disinformation Age. New York: Columbia University Press. 
Nduka, Emmanuel-Lugard, and John McGuire. 2017. The Effective Use of New Media in Disseminating Evangelical Messages Among Catholic College Students. Journal of Media and Religion 16: 93-103. [CrossRef]

Neuberger, Christoph, Christian Nuernbergk, and Susanne Langenohl. 2019. Journalism as Multichannel Communication. Journalism Studies 20: 1-21. [CrossRef]

Nielsen, Rasmus Klaus, and Kim Christian Schrøder. 2014. The Relative Importance of Social Media for Accessing, Finding, and Engaging with News. Digital Journalism 2: 472-89. [CrossRef]

Nowak, Jakub. 2012. Social media jako sieci obiegu przekazów medialnych. Nowe Media 3: 13-31. [CrossRef]

Olszański, Maciej. 2012. Media i Dziennikarstwo Internetowe. Warszawa: Wydawnictwo Poltext.

Parzyszek, Czesław. 2010. Treść pojęcia 'nowa ewangelizacja’ według Jana Pawła II. Kultura-Media-Teologia 2: 135-51. [CrossRef]

Peterson, Kristin. 2019. Pushing boundaries and blurring categories in digital media and religion research. Sociology Compass 14: 1-11. [CrossRef]

Pokorna-Ignatowicz, Katarzyna. 2002. Kościót w Świecie Mediów. Historia-Dokumenty-Dylematy. Kraków: Wydawnictwo Uniwersytetu Jagiellońskiego.

Pokorna-Ignatowicz, Katarzyna. 2007. Media katolickie w III RP i ich wkład w budowę polskiej demokracji. In Media a Demokracja. Edited by Lidia Pokrzycka and Włodzimierz Mich. Lublin: Wydawnictwo Uniwersytetu Marii Curie Skłodowskiej, pp. 119-30.

Przybysz, Monika. 2018. Kościół w social media. Komunikacja instytucji eklezjalnych w mediach społecznościowych w perspektywie medioznawczej i teologicznej. Kultura-Media-Teologia 35: 140-66. [CrossRef]

Rončáková, Terezia. 2018. Strengths And Weaknesses of The Church Media in Slovakia. Informatol 51: 206-15. [CrossRef]

Sadłoń, Wojciech, Sławomir Nowotny, Bartosz Łukaszewski, and Luiza Organek. 2019. Czas wolny w Życiu Polaków a Świętowanie Niedzieli. Analiza Wyników badań. Warszawa: Instytut Statystyki Kościoła Katolickiego SAC im. ks. Witolda Zdaniewicza, Available online: www.przemyska.pl (accessed on 7 March 2020).

Sawicka, Zofia. 2019. How Facebook Polarizes Public Debate in Poland-Polish Filter Bubble. Social Communication Online Journal 2: 45-52. [CrossRef]

Sellas, Toni, and Tiziano Bonini. 2014. Masters of brand: A study of social media workers in the Italian and Spanish radio industries. In Radio: The Resilient Medium, Papers from the third conference of the ECREA Radio Research Section. Sunderland: University of Sunderland, pp. 65-82.

Seweryniak, Henryk. 2010. Teologie na "progu domu". Kultura-Media-Teologia 1: 10-23. [CrossRef]

Sierocki, Radosław. 2018. Praktykowanie Religii w Nowych Mediach. Katolicka Przestrzeń Facebooka. Toruń: Wydawnictwo Adam Marszałek.

Siuda, Piotr. 2010. Religia a Internet. O przenoszeniu Religijnych granic do Cyberprzestrzeni. Warszawa: WAiP.

Soukup, Paul A. 2019. Some past meetings of communication, theology, and media theology. Kultura-Media-Teologia 3: 25-46. [CrossRef]

Spadaro, Antonio. 2013. Benedetto XVI, Teologo Della Comunicazione Digitale. Cyberteologia.it. 21.02. Available online: http://www.cyberteologia.it/2013/02/benedetto-xvi-teologo-della-comunicazione-digitale/ (accessed on 20 February 2020).

Stępniak, Krzysztof. 2019. Reklama religijna a nowa ewangelizacja. Wyzwania i możliwości. Łódzkie Studia Teologiczne 1: 191-206.

Szews, Przemysław. 2014. Facebook, Twitter i YouTube w mediach tradycyjnych. Jak prasa, radio i telewizja wykorzystuja serwisy społecznościowe? Media i Społeczeństwo 4: 55-73.

Todorczuk, Adrian. 2013. Najlepsze Sposoby na Social Media. Available online: https://www.press.pl/magazynpress/artykul/31940,najlepsze-sposoby-na-social-media (accessed on 20 February 2020).

Tudor, Mihaela Alexandra, and Stefan Bratosin. 2020. French Media Representations towards Sustainability: Education and Information through Mythical-Religious References. Sustainability 12: 2095. [CrossRef]

Webb, Marion S., Benoy W. Joseph, Kurt Schimmel, and Christopher Moberg. 1998. Church Marketing: Strategies for Retaining and Attracting Members. Journal of Professional Services Marketing 17: 1-16. [CrossRef]

Wilk, Dorota. 2018. Role And Room For Social Broadcaster With Radio Fara As An Example. Social Communication Online Journal 2: 16-19. [CrossRef] 
Wilkoń, Tomasz. 2018. Polish Opinion Weeklies' Thematic Spectrum Analysis-Methodology and Application. Social Communication Online Journal 4: 6-22. [CrossRef]

Woźniak, Jarosław. 2015. Rozwój mediów w przekazie wiary w archidiecezji lubelskiej po roku 1989. Lublin: Gaudium. Wrenn, Bruce. 2011. Religious Marketing is Different. Services Marketing Quarterly 32: 44-59. [CrossRef]

(C) 2020 by the authors. Licensee MDPI, Basel, Switzerland. This article is an open access article distributed under the terms and conditions of the Creative Commons Attribution (CC BY) license (http://creativecommons.org/licenses/by/4.0/). 